\title{
Military Spending and Differential Accumulation: A New Approach to the Political Economy of Armament - The Case of Israel
}

\section{Shimshon Bichler and Jonathan Nitzan}

\begin{abstract}
This paper offers a new approach to the political economy of armament, focusing on the relationship between military spending and differential accumulation in mature capitalist economies. Applied to the "model" case of Israel, our analysis suggests that the militarization of Israel's economy since the late 1960 s occurred within a growing dichotomy between large and small firms. The econometric model shows that the "military-bias" of Israeli industry raised the profits of the large corporate conglomerates but constrained and even lowered those of smaller companies.
\end{abstract}

The 1980 s marked a significant watershed in the international military economy. For the first time in recent memory, world military budgets (measured in constant dollars) moved downward, initially in the developing countries, and then, toward the end of the decade, also in the developed world. This tendency was further enhanced in the early 1990 s by the collapse of the Soviet Union and the end of the Cold War. Soon, it became fashionable to talk about a forthcoming "peace dividend." The hope was that, with receding world tensions, economic resources which previously were tied up to defense needs would now help rejuvenate the sluggish western economies and facilitate the daunting task of cleaning and protecting a deteriorating global environment. Yet these

Dept. of Political Science, Jesrael College, Afula and The Davis Institute for International Relations, Jerusalem, Israel.

Dept. of Social Science \& Commerce, Marianopolis College, Montreal, Quebec, H3H-1W 1, Canada.

(C) 1996 Union for Radical Political Economics.

Published by Blackwell Publishers, 238 Main St., Cambridge, MA 02142, USA, and 108 Cowley Rd, , Oxford, OX4 1JF, UK. 
sanguine expectations could prove too optimistic. Global military expenditures remain very large at about $\$ 870$ billion a year, or roughly $5.7 \%$ of the world's GNP (U.S. Arms Control and Disarmament Agency, 1993-1994: 43). This means that, despite recent declines in annual spending, the international weaponry arsenal still continues to grow at a rate sufficiently rapid to intensify existing conflicts and induce new ones; if those conflicts are allowed to develop, they could then reverse the very trend of falling military budgets. According to the Stockholm International Peace Research Institute (1992: 418), there are currently over 30 major conflicts waging worldwide, and so far there is little reason to expect a significant reduction in that number. Indeed, some regions - particularly South-East Asia and the Middle East - have recently embarked on a renewed path of rearmament, with the obvious implications for future instability.

Given the issues at stake - notably, global peace and security, economic prosperity and a sustainable environment - the future of armament is clearly a crucial question. The prospects for a less militarized world depend to a large extent on the developed countries. According to U.S. Arms Control and Disarmament Agency, 1993-1994: 2, 14), in 1993 these countries accounted for about $75 \%$ of global military expenditures and $92 \%$ of all arms exports, and, although armed conflicts and wars often occur in the developing world, the political and economic role of the industrialized countries is clearly paramount. How likely, then, are these countries to continue and reduce their military production and exports? The answer to this question is of course highly complex, yet one aspect looms large and that is the two-way interaction between arms production and business structure. Over time, military spending tends to affect the evolution of the corporate sector and alter the balance of power between its constituent components. These changes need not be significant of course, but when they are, one of their possible consequences is to augment the political clout of some of the affected groups, perhaps to the extent that they can then influence the course of military budgets and arms exports. Thus, any attempt to understand the development of military spending and, by extension, the prospect for future changes, should take into consideration these structural consequences of the war economy.

In this paper, we offer a new analytical approach to the relationships between military expenditures and economic 
structure in mature capitalist countries. In developing this framework, we focus on the "model" case of Israel. The Israeli example is instructive for a number of different reasons. First, Israel experienced significant changes in the level of military expenditures at the same time that its corporate sector was undergoing drastic restructuring. Second, these developments were very rapid and intense, thus heightening important turning points and crucial political considerations that otherwise could go undetected. Third, by virtue of its key role in the Middle East, the Israeli case may help shed more light on the evolution of the Arab-Israeli conflict and the prospects for its reconciliation. And, fourth, the apparent link between military spending and the transformation of Israel from a developing country to a mature industrial economy may carry interesting implications for other countries that are going through a comparable transition and face similar problems.

Theoretical and empirical attempts to deal with military spending are usually based on some explicit or implicit assumption regarding the underlying structure of society. One approach is to begin by assuming that the actions of a "nation" reflect some commonly shared set of interests. In this aggregate framework, it is customary to subdivide society into two systems of "economics" and "politics." The economic system, so it is assumed, would guarantee universal welfare if only it were allowed to function "efficiently." The political system may undermine that efficiency when it seeks to achieve additional goals such as "national security" but fails to find the optimal rate of substitution between security and economic growth along the nation's production-possibility frontier. Seen from this perspective, military spending appears to be governed by politicians who are free to choose between a rational action toward "correct" decisions, or a passionate behavior leading to inevitable "mistakes." The literature on defense economics in Israel is dominated almost exclusively by these presumptions and is preoccupied with the "optimal" choice between security and alternative economic goals. The seminal article by Berglas (1983), for example, attempted to weigh the economic "burden" of military spending, while Sadan (1985) expanded the

${ }^{1}$ The notion that politicians are indeed free to choose and hence tend to "err" is deeply embedded in the historical theories of Schumpeter (1919) and Tuchman (1984). On the "mistake theory," see Barnet (1972: $7,125)$. 
framework to assess the security burden on the social system as a whole. ${ }^{2}$

An alternative disaggregate perspective is to recognize the primacy of social conflict as a factor affecting military spending. The roots of this approach could be traced to early Marxist and institutional writers who attempted to explain military spending as part of a dialectical process of capitalist crises. An important school within this literature focused on the tendency toward under consumption and the rise of monopoly capital. The first contributors in that direction notably Hilferding (1910), Luxemburg (1913) and Veblen $(1904,1923)$ - tied the increase in military spending and the tendency toward aggressive foreign policy with the process of corporate concentration in advanced capitalist economies. Later writers, such as Kalecki (1971, 1972), Steindl (1952), Tsuru (1961) and Baran and Sweezy (1966), argued that the rising "degree of monopoly," created a "tendency of surplus to rise" but without a corresponding increase in potential "offsets to savings." This, in their opinion, led to the growing use of defense spending - or what Gold (1977) later labeled as "military Keynesianism" - in order to prevent declines in aggregate output and employment. Some contemporary contributors, like O'Connor (1973) and Griffin, Devine and Wallace (1982), have taken the argument a step further, suggesting that government involvement in general, and military expenditures in particular, were affected not by overall macroeconomic needs, but by the specific requirements of dominant economic groups.

Notably, both the aggregate and disaggregate approaches focus on the effect of an underlying structure on the behavior of overall economic aggregates. The first of these approaches views military spending as related to the macroeconomic and macropolitical preferences of a nation, while the second associates such spending with an antagonistic economic and power structure. Yet, both frameworks are to a certain extent unidirectional. They seek to explore the effect of a given structure on the behavior of military expenditures and tend to ignore the potential impact of military spending on structure. There is, of course, no presumption that underlying structures

${ }^{2}$ The dilemma over the "right" allocation of resources underlies numerous other studies such as Barkai (1981), Gilshon (1986), Gross (ed.) (1975), Hassid and Lesser (1981), Katzir and Shadmi (1984) and Zusmman (1984). 
remain unaltered. Instead, the implicit assumption is that, for the purpose of analysis, structure could be taken as given. However, this convenient avenue could prove misleading. The process of restructuring may not be as exogenous as some researchers tend to assume, and whenever this happens to be the case, there is a need for a broader, double-sided approach that recognizes not only the impact of structure on military spending, but also the effect of military expenditures on structural change.

One of the first scholars to stress this latter link between military spending and changes in the structure of economic and political power was Kalecki $(1964,1967)$. He predicted that military expenditures on the Vietnam War would shift the center of business power from "civilian" to "military" industries and that this restructuring would increase the influence of "angry elements" within the U.S. elites. The experience since the late 1960 s lends considerable support to this contention. First, the share of large armament firms in the net profit of the "big economy" in the U.S. seems to have increased more or less continuously between the late 1960 s and the late 1980 s. Second, many large firms that were traditionally limited to civilian markets, have gradually increased their reliance on military-related production. ${ }^{3}$ We believe a comparable (though by no means identical) restructuring has occurred in the Israeli case.

Figure 1 describes the changing significance of military spending in Israel between 1960 and 1985. Expressed as a share of GDP, domestic military spending (which includes local procurement and wages but not military imports) has risen sharply from about $6 \%$ in the mid- 1960 s, to over $17 \%$ by the mid-1970s and then declined to a lower share of about $15 \%$. Another viewpoint, which focuses only on net sellable output (with the exclusion of replacement investment, rent and

${ }^{3}$ Based on data published in the Fortune 500 listings and in the U.S. Department of Defense's 100 Companies Receiving the Largest Dollar Volume of Prime Contract Awards, the 16 largest Pentagon contractors increased their share in the net profit of the 500 largest industrial corporations from $4.1 \%$ in 1969 , to a record $10.7 \%$ in 1985 . The emergence and consolidation of an "armament core" of large U.S. -based corporations is explored in Bichler, Rowley and Nitzan (1989), Nitzan, Rowley and Bichler (1989), Rowley, Bichler and Nitzan (1989), and Nitzan and bichler (1995). 
Figure 1

The Israeli War Economy

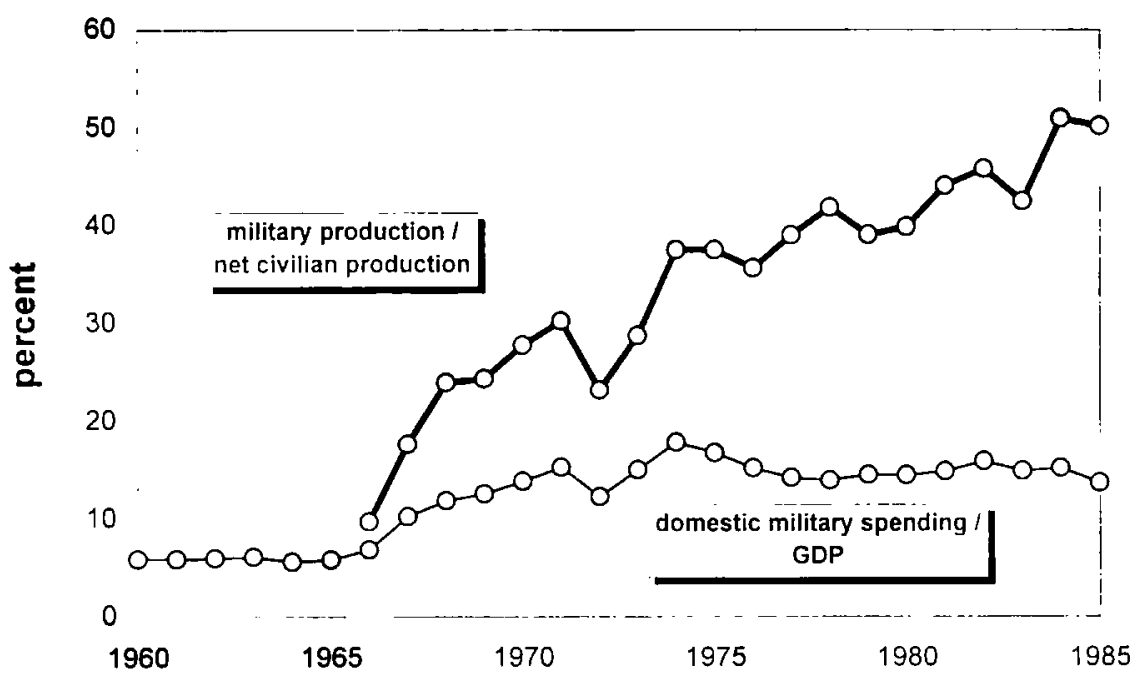

Source: Statistical Abstract of /srael.

government wage payments as described in section 3), shows a dramatically different picture, however, with the ratio between overall military production and overall net civilian production rising more or less continuously from about $10 \%$ in the mid-1960s, to over $50 \%$ by the mid-1980s. ${ }^{4}$ These changes were accompanied, since the early 1970s, by a severe stagflation, characterized by rapid inflation, stagnating or falling output, declines in investment and deteriorating public services. In parallel to these macroeconomic changes, there were dramatic transformations affecting the underlying structure of the business sector. Perhaps the most significant of those changes was the emergence of differential capital accumulation - that is, a combination of rising profits at the corporate core together with stagnating or falling profits in the rest of the business sector. The consequence of this differential process was the progressive consolidation of the "big economy," whereby the five largest Israeli conglomerates have increased their share of the economy's net profit from less than $3 \%$ in the

${ }^{4}$ In the third section, this ratio is defined as equal to $($ Drril $+X m i l) \div($ Dciv $+X c i v)$. 
early 1970 s, to over $20 \%$ by the early 1980sl (See Figure 2 below.)

Our purpose in this article is to explore the relationship between the process of differential capital accumulation and the development of military spending in Israel, focusing specifically on the economy's "militarization phase" between 1966 and 1985 . To the extent that such a relationship exists, it must be situated within a broader context of economic and political changes which occurred over that period. Thus, in the second section, we outline the dual-economy structure of Israel. We argue that the historical evolution of this structure and the emergence of its leading core firms via differential accumulation has been affected by the macroeconomic development of Israel, particularly (thought not only) by its growing "military bias" toward defense-related production. The third section offers a new analytical framework for relating macroeconomics and market structure. Specifically, we establish a self-contained set of definitional equations describing the quantitative relationship between the aggregate categories of the national accounts on the one hand, and the differential accumulation of net profit by large and small firms on the other. The novelty here is twofold. First, instead of looking at conventional variables such as sales, value-added or employment, we make net profit and the distribution of profit the focus of our structural analysis. Second, rather than groping for miscellaneous determinants of differential accumulation, we construct a closed system - one in which the micro redistribution of profit is part of the same transformation that also alters the macro relationships among the different components of the national accounts. In the fourth section, we use this analytical framework as a basis for developing an econometric model. Applied to the Israeli economy, this model is then employed to evaluate the relative importance of military-related production in the differential evolution of Israel's market structure. In concluding, we comment on the broader significance of our study for understanding the long-term development of the Israeli economy, and on the prospects for its future demilitarization.

\section{THE ISRAELI DUAL-ECONOMY}

The core of Israel's big economy comprises five corporate conglomerates - Bank Hapoalim, Bank Leumi, Israel Discount Bankholding (IDBH), Koor and Clal. These groups are directly 
or indirectly involved in all key sectors of the economy - from raw materials, through transportation, to production, marketing, services and finance. Their origins predate Independence in 1948, and their evolution has been marked by strong and symbiotic relations with the government. Over the years, cross-ownership, kinship, status and cultural ties among the owners and managers of these companies have slowly consolidated this group into a single "core," which in relative terms is probably much more cohesive than its U.S. counterpart (as described in Borwring 1986, for instance). This cohesiveness is reflected in the high correlation exhibited between the performance of the different groups - in sales, value-added, taxes, subsidies, executive compensation and, most significantly, net profits. ${ }^{5}$

The core conglomerates are surrounded by a satellite belt of somewhat smaller firms, usually occupying a leading or even monopoly position in a particular industry. Most of these satellite firms are closely linked to one or more of the core conglomerates through business, credit and ownership ties, and often exhibit similar financial performance (Rowley, Bichler and Nitzan 1988, and Levi 1979, 1981). On the outer "periphery" of the Israeli economy we can find a multitude of much smaller corporations, proprietorships and partnerships which usually operate a single establishment. Unlike the groups of the "big economy," the "small-economy" firms function independently from one another, with only loose business and professional associations. Most interestingly, although they operate in the same macroeconomic environment, the "big" and "small" economies demonstrate different and often diametrically opposed business performances - particularly in terms of value added and net profits (Rowley, Bichler and Nitzan, 1988).

\section{Differential Capital Accumulation and the Aggregate}

Concentration of Profit

In analyzing business structure, the conventional approach is to concentrate on the size-distribution of corporate assets,

${ }^{5}$ For a comprehensive statistical analysis of the corporate conglomerates, see Rowley, Bichler and Nitzan (1988). The history of Israel's business elites and its relationship with the political and military elites is examined in Frenkel and Bichler (1984). The interaction between the "big economy" and the government in Israel was first analyzed in Aharoni (1976). 
sales, value-added or employees. In this article, however, we prefer to focus on the less conventional but perhaps more useful variable of net profit. The reasons for this choice are relatively straightforward, but given the common neglect of profit, a brief elaboration may prove useful. In the modern system of business enterprise, the number of employees, value-added and revenues from sales are merely means toward the final goal of capital accumulation. Furthermore, even the value of assets (or equity) - the professed end of accumulation - is not an independent quantity but rather a capitalization of earning capacity. In other words, stripped to its bare essentials, the quest for accumulation is ultimately a pursuit of net profit. At the same time, the economic and political power needed to appropriate future profits often hinges on the corporation's previous earnings, so that profit is not only the end, but also the most substantial means of business activity. Indeed, in the modern business world, the final yardstick for corporate success derives not from the expansion of sales, value-added or employment, but from the growth of net income.

Taking this reasoning one step further, the main focus of our analysis is on the related concepts of differential accumulation and the aggregate concentration of profit. ${ }^{6}$ For the modern corporation, the benchmark for assessing success or failure is rarely the "maximum" rate of profit (which is always unknown), but rather the all-pervasive "average" or "normal" rate of return. In the context of large-scale business enterprise, the main goal is to "beat the average." Ultimately, the large firm seeks to have its profit rise faster than the average - that is, to achieve a differential rate accumulation. But exceeding the average pace of accumulation is tantamount to raising one's share in the overall flow of profit, so, in the final analysis, differential accumulation and rising aggregate concentration of profit are two sides of the same process.

${ }^{6}$ Note that the concept of "accumulation" is used here in a pecuniary, not material sense. The monetary value of capital may of course be affected by the material augmentation of industrial equipment; from a business perspective, however, such tangible expansion is merely one way - and certainly not the only one - toward the more fundamental goal of pecuniary accumulation. The pivotal significance of differential pecuniary accumulation in the evolution of mature capitalism is developed in Nitzan (1992) and Nitzan and Bichler (1995). 
This vantage point is highly significant for our purpose because, by concentrating on differential accumulation and the distribution of profit, we are effectively looking right at the very essence of business restructuring. Other aspects of restructuring, such as changes in industrial concentration, technological superiority, political ties, or international competition are of course very important, but only as means toward the higher end of differential accumulation. These considerations fit neatly with our own theoretical framework for linking macroeconomic and structural changes developed in the third and fourth sections. Our analysis of income and expenditure flows makes net profit the proper variable of choice, whereas the dual-economy disaggregation centers around the differential aspect of accumulation and the resulting changes in the aggregate concentration of profit.

\section{Macroeconomic History in Structural Retrospect}

The interaction between macroeconomic development and differential accumulation in Israel could be perceived as belonging to two distinct "regimes": (1) The period between 1955 and 1972, characterized by rapid macroeconomic growth and "latent" structural consolidation, and (2) the post-1973 era, marked by severe stagnation and an "open" process of differential accumulation. (The early 1990s may mark the beginning of a third regime of "peace dividends" as argued in Nitzan and Bichler 1996a, 1996b) These broad contours are illustrated in Figure 2, where we contrast the economy's GNP growth (expressed as a five-year moving average) with the rate of aggregate concentration as measured by the share of the five core conglomerates in the net profit of the entire business sector. During the 1955-1972 period, the economy expanded at an average annual rate of $10 \%$. The profit share of the core conglomerates, on the other hand, was relatively low and, between 1966 and 1972, never exceeded 3\%. (Although prior data are unavailable, the profit share must have been even lower during earlier years, when the large conglomerates were just beginning to consolidate.) The post-1973 period was fundamentally different: there was a marked drop in growth rates, to an average of $3 \%$ between 1973 and 1985, and as the stagnation lingered, the profit share of the core firms started to rise rapidly, climbing as we already noted from less than $3 \%$ in the early 1970 s, to an average of $15 \%$ during the early 1980 s. The distinction between these two "regimes" is 
Figure 2

Macroeconomic Growth and Differential Accumulation

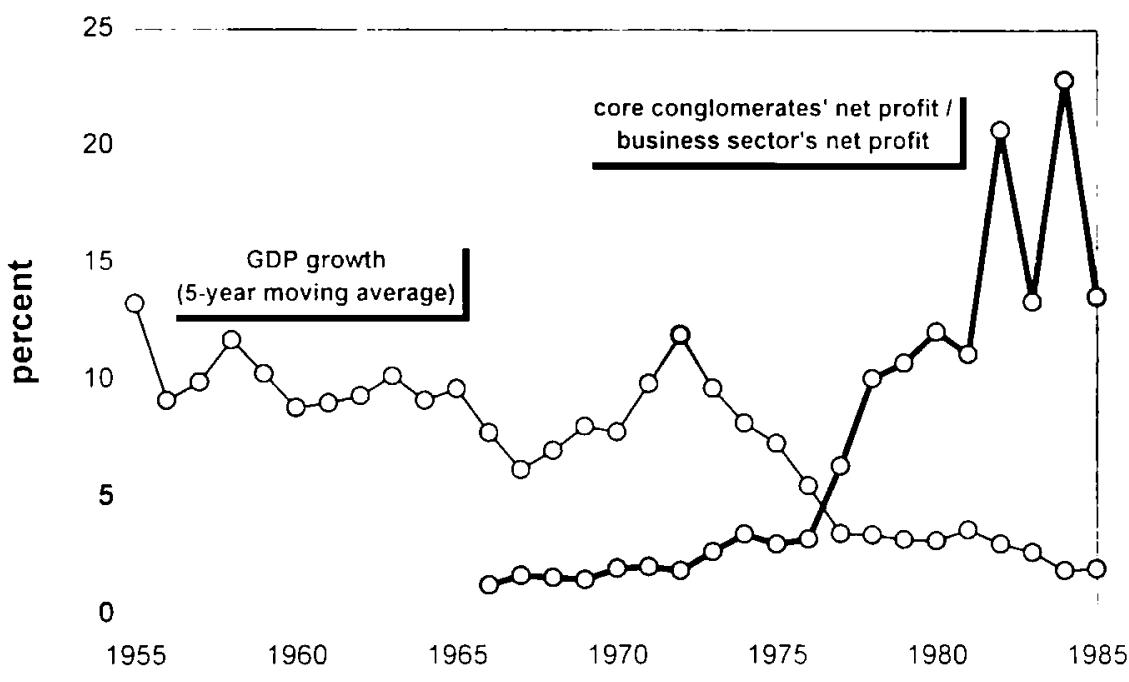

Source: Statistical Abstract of Israel; company annual reports.

important, and we turn to consider it now, beginning with the first period.

Until 1972, economic growth in Israel was disproportionately affected by two "external" stimuli: (1) the unilateral capital inflow of German compensation between 1955 and 1965, and (2) the "Palestinians boom" in the immediate years after the 1967 War. During the 1955-1965 period, unilateral transfers from Germany accounted for most of the capital import, and, until the early 1960 s, their levels were almost identical to the annual change in GNP. Indeed, the end of these transfers in 1965 was followed by the severe recession of 1966-1967. The situation changed again in 1968, when the Israeli market suddenly expanded to include 1 million new consumers from the occupied territories of the West Bank and Gaza Strip. Furthermore, the postwar years, roughly until 1973, saw very rapid increases in the number of Palestinian employees working in Israel - from zero to over 60,000 in just five years - and a consequent increase in purchasing power. This combination of an overnight expansion of markets and a rapid process of proletarianization had a decisive multiplier effect on the Israeli economy. Indeed, by 1974, when growth in the 
number of Palestinians working in Israel dropped sharply, the economy reverted back to stagnation. ${ }^{7}$

These external impetuses to growth worked to lessen the process of aggregate concentration, mainly through their positive impact on the expansion of small firms. Yet, underlying the overall growth process, one could (in retrospect) identify the early emergence of the would-be conglomerates. Consolidation in the financial sector began already during the $1950 \mathbf{s}^{8}$ while the amalgamation of industrial concerns began in the 1960 s, with the government's gradual retreat from manufacturing. Although the large conglomerates remained relatively small in quantitative terms until the 1970 s, they were nevertheless establishing and fortifying special relationships with the government and among themselves. ${ }^{9}$ Particularly significant in that respect was the recessionary period of 1966-1967, which enabled the emerging core groups to diversify their holdings and increase their mutual integration.

This "latent" reorganization has slowly altered the underlying institutional structure of the Israeli economy, paving the way for a new regime of "open" differential accumulation and persistent stagnation. Following the 1973 collapse of the "Palestinian boom," it became increasingly clear that the Israeli economy could not grow "on its own." Initially, the recession was blamed on the 1973 oil crisis, but as stagnation continued to linger, economists started pointing their fingers at chronic "market imperfections": reckless politicians, a socialist tradition that promoted excessive government intervention, an omnipotent labor union, a commitment to full employment and

${ }^{7}$ Data on the number of Palestinians working in Israel are from the Statistical Abstract of Israel for 1983 (774-775) and for 1986 (770). Note that this view, which attributes the post-1967 economic growth to the rapid expansion of markets and proletarianization of the Palestinian population, has for long been rejected by many Israeli economists (see, for example, Tuma 1989: 139). Interestingly, though, this hypothesis received some indirect support recently, when many observers noted the detrimental impact on the Israeli economy of declining Palestinian employment and purchasing power during the Intifada.

${ }^{8}$ See Elizur (1984) and Greenberg (1986). According to Heth (1966), there were 70 commercial banks and 100 savings and loans cooperatives operating in Palestine of the 1930 s. By the early 1970s, there remained only five banking groups, of which three were part of the large conglomerates.

${ }^{9}$ Cf. Frenkel and Bichler (1984), and Shapiro (1977, 1984). 
various international obligations which ailed the economy and "misallocated" its resources. ${ }^{10}$ What these explanations tend to miss, however, is the intimate link which exists in Israel (and elsewhere) between macroeconomic "distortions" and business restructuring.

The allocation of resources during the 1950s and 1960s was not even distributed across the business sector. For example, the "Sapir Method" of allocating the German transfer payments (named after Pinchas Sapir, the Labor Minister of Finance) was to supply cheap capital to selected business groups and entrepreneurs, which were considered conducive to industrial development and employment growth. This kind of government "intervention" was not a random violation of competitive allocation; instead, it followed a systematic pattern that contributed toward the progressive concentration of the Israeli economy. ${ }^{11}$ Initially, the negative effect on growth was relatively mild. The redistribution of income in favor of selected business groups and away from smaller firms and labor tended to curtail mass consumption, but given that capital formation was closely administered by the government, the shortfall in the demand for wage goods was compensated by higher levels - of investment. The problem arose in the early 1970s, when the external sources of growth dried up. By that time, the "misallocation" of resources had already grown into a rigid set of institutional arrangements between the government and the key business players, arrangements that could no longer be easily altered. It was from that point onward that the dual-market distinction between the "big" and "small" economies became crucial to understanding Israel's broad economic development. ${ }^{12}$

${ }^{10}$ See, for instance, Ben-Porath (1986), Bruno (1989) and Sharkansky (1987). An earlier analysis is given in Patinkin (1965).

1 "The "Sapir Method" and some of its important structural ramifications are examined in Barkai (1968).

${ }^{12} \mathrm{~A}$ parallel process of segmentation has been proposed by Farjoun $(1978,1980,1983)$, who described the growing dichotomy between the primary and secondary labor markets. With the 1967 occupation of the West Bank and Gaza Strip, and the concurrent militarization of the "big economy," writes Farjoun (1978: 4), "came a growing need for a cheap, mobile labor force, with no social rights; a free labor force in the classical meaning of the term." This was achieved by the proletarianization of the Palestinian population, which was rapidly becoming the main labor pool for a growing number of "small-economy" sectors, such as agriculture, 
Following Olson (1982), one could argue that, by 1973, Israel has accumulated a dense network of "distribution coalitions" with little incentive to promote macroeconomic growth. The long period of "administered" capital formation helped to consolidate the relative position of large firms, but, without comparable increases in real wages, it also created a serious predicament of excess capacity (that is, an excess over what could be sold at profitable prices). With the subsiding of the post-1967 boom, there was a dramatic decline of net investment - from 21 billion New Israeli Shekels (NIS) in 1973 , to 12 billion NIS in 1978, to 5 billion NIS in 1986 (all in 1980 prices) - as the "big economy" shifted its focus from productive to distributional activities. ${ }^{13}$

This transition consisted of three principal developments. First, there was a surge of mergers and acquisitions, mostly by the core conglomerates (particularly Koor, Clal and IDBH), but also by some of the satellite firms (like Danot, Dubek and Elite). The ensuing process of concentration worked to reduce both excess capacity and competition simultaneously, which in turn helped maintain and even increase profit margins on lower volumes. Second, the decline in industrial "offsets to savings" diverted funds to the stock and bond markets, causing a rapid speculative inflation in the value of financial assets. With the prices of these assets rising even faster than prices of goods and services, the ratio of stock market capitalization to GNP rose from less than $8 \%$ in 1973 , to $99 \%$ in $1982 .{ }^{14}$ Particularly affected were the assets of the core conglomerates: according to the Commission of Inquiry to the Regulation of Bank Shares (Bejsky, Ziller, Hirsh, Sarnat and Friedman 1986: 61), shares of the three largest banks, which accounted for $7 \%$ of the aggregate value of all financial assets in 1973, rose to $44 \%$ of that total by 1982, and it is thus hardly surprising that the large conglomerates became the largest owners (and

construction, services and low-technology civilian manufacturing. The other side of this process was that the "big economy," particularly its financial and military branches, came to rely solely on a Jewish, unionized labor force, with relatively extensive social security and wage rates twice as high as those earned by the Palestinians (17).

${ }^{13}$ Figures are based on the Statistical Abstract of Israel, various years.

${ }^{14}$ Data on stock market capitalization are from the Bank of Israel's Annual Report 1974, p. 445 and Annual Report 1983, p. 282. GNP figures are from the Central Bureau of Statistics' National Accounts, 1972-1985, p. 166. 
manipulators) of their own stocks! ${ }^{15}$ Third, and perhaps most important, was the increasing dependency of the "big economy" on military-related profits.

\section{The "Military Bias"}

Although government policies since the early 1970s enhanced the extent of mergers and acquisitions as well as the diversion from industrial to speculative activity, it was defense spending that, in our view, exerted the most lasting effect on both the underlying structure of the Israeli economy and its overall performance. To the extent that the government maintained or even increased the military-related profitability of the large firms, it contributed toward undermining the long-term viability of the Israeli economy. Much like the transformation of U.S. big business, as predicted by Kalecki (1967) and later analyzed by Melman (1985), the growing "military bias" since the early 1970 s became the dominant structural process of Israel's "big economy." This "military bias" shifted the industrial focus toward areas in which Israel did not have and could not have any competitive edge. It raised the domestic and foreign debt and increased Israel's dependence on the United States. Most significantly, through its effect on the aggregate concentration of profit, it turned the large conglomerates into a decisive political force. Indeed, since the early 1980s, a growing number of mainstream Israeli economists started to express concern about the backward link between the "military bias" of Israeli industry and the course of Israel's foreign policy: defense spending was no longer seen as a mere political issue, but also as a reflection of economic pressures exerted by the "angry elements" that came to dominate many boardrooms in the "big economy."16

${ }^{15}$ On the systematic regulation of stock prices in the Tel-Aviv Exchange, see also Elizur (1984) and Frenkel and Bichler (1984).

${ }^{16}$ Although the "militarization" of the Israeli economy and its broader political-economic implications have never been systematically analyzed in Israel, there are several works that need to be mentioned. Perhaps the most cited study, by Peri and Neubach (1985), asserted that there exists in Israel a "military-industrial complex" along the lines proposed by Mills (1956). Unfortunately, these authors provided no empirical evidence to substantiate their claim. Another article by Halperin (1987) argued that, after 1973, Israeli industry underwent a structural change that shifted its focus toward investing in military production and high-technology ventures and that this shift has led to permanent stagnation. Yet, here, 
The evolution of military spending in Israel was hence part of a double-sided structural transformation. On the one hand, the level of military expenditures was influenced by the progressive "military bias" and increasing concentration of the Israeli economy. On the other hand, these latter developments were themselves partly the outcome of high military spending. Given the attendant difficulty of separating cause from effect within this intricate historical process, our purpose in the rest of this paper is primarily descriptive: we seek to unravel the actual evolution of structural interactions. ${ }^{17}$ In order to do that, we develop in the next section an analytical framework that anchors the process of differential accumulation in the income and expenditure categories of the national accounts.

\section{THE MACROECONOMICS OF STRUCTURAL CHANGE: AN ANALYTICAL FRAMEWORK}

Consider the GDP identity between income and expenditures, such that

$$
W+K I+T i-S U B+D \equiv C+I+G+X-M,
$$

where $W$ is Wages and Salaries, $K I$ is Capital Income, $T i$ is Indirect Business Taxes, $S U B$ is Subsidies to Business, $D$ is Depreciation, $C$ is Private Consumption, $I$ is Gross Investment, $G$ is Government Consumption Expenditures, $X$ is Exports and $M$ is Imports. Note that, in this standard definition, Capital Income $(K I)$ includes, in addition to the share of capital in value- added, also Subsidies to Business (SUB) and Direct Business Taxes $(T d)$. A portion of this income - namely, rent from the ownership of dwellings $(R)$ - is paid (or imputed) directly to households that are not considered part of the business sector. Furthermore, as it stands, $K I$ excludes the Interest Payments on the Domestic Debt (IDD). In Table 1, we

too, the conclusion was not backed by evidence. A third analysis that appeared in a series of nine journalistic articles by Frenkel (1982) examined the complex ties of business, politics, kinship and ideology existing among Israel's business, military and political elites, as well as the relationships of these groups with the elites of the United States.

${ }^{17}$ For recent atternpts to identify the causal "determinants" of Israel's military spending, see, for example, McGuire (1982), Mintz and Ward (1989) and Mintz, Ward and Bichler (1990). 
Table 1

Net Domestic Product Less Rent

\begin{tabular}{|c|c|c|}
\hline & Income & Expenditures \\
\hline$\therefore$ & Wages and Salaries & $\begin{array}{l}\text { Cld Private Consumption } \\
\text { less Dwelling } \\
C \text { Private Consumption } \\
-R \text { Rent }\end{array}$ \\
\hline $\begin{array}{l}\pi \\
\therefore \\
.\end{array}$ & 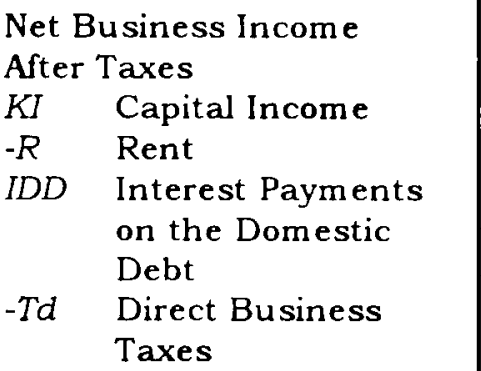 & $\begin{array}{l}\text { Inet Net Investment } \\
I \text { Gross Investment } \\
-D \text { Depreciation }\end{array}$ \\
\hline$-I D D$ & $\begin{array}{l}\text { Interest Payments on } \\
\text { the Domestic Debt }\end{array}$ & $\begin{array}{ll}G \quad \text { Government } \\
\text { Consumption } \\
\text { Expenditures }\end{array}$ \\
\hline & : & $\begin{array}{ll}\text { Gmil } & \text { Military } \\
& \text { Procurement }\end{array}$ \\
\hline$\therefore$ & 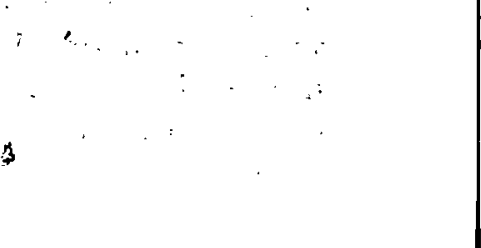 & $\begin{array}{ll}\text { Gciv } & \text { Civilian } \\
& \text { Procurement } \\
\text { Gwmil } & \text { Military Wages and } \\
& \text { Salaries } \\
\text { Gwciv } & \text { Civilian Wages and } \\
& \text { Salaries }\end{array}$ \\
\hline$T d$ & Direct Business Taxes & $\begin{array}{ll}X \quad \text { Export } \\
\text { Xmil } & \text { Military Export } \\
X c i v & \text { Civilian Export }\end{array}$ \\
\hline$T i$ & Indirect Business Taxes & $\begin{array}{l}-M \quad \text { Import } \\
-M m i l \quad \text { Military Import } \\
-M c i v \text { Civilian Export }\end{array}$ \\
\hline$-S U B$ & $\begin{array}{l}\text { Subsidies to } \\
\text { Business }\end{array}$ & \\
\hline
\end{tabular}

define Net Business Income After Taxes $(\pi)$ as equal to $(K I-R$ $+I D D-T d)$ and substitute $\pi$ for $K I$. In parallel, we add (-IDD + 
$T d)$ to the left-hand side of the national-accounting identity and, on the right-hand side, deduct $R$ from Private Consumption (C) to obtain Private Consumption less Dwellings (Cld). Next, we substitute Net Investment (Inet) for Gross Investment $(I)$ in the expenditure side and eliminate Depreciation $(D)$ from the income side, so both sides are now equal to the net domestic product less rent. Then, we decompose Government Consumption Expenditures $(G)$ into Military Procurement (Gmit), Civilian Procurement (Gciv), Military Wages and Salaries (Gwmil) and Civilian Wages and Salaries (Gwciv). Finally, we distinguish between Military Export (Xmil) and Civilian Export (Xciv), as well as between Military Import (Mmil) and Civilian Import (Mciv).

In Table 2, we move everything but $\pi$ from the left-hand to the right-hand side and, by rearranging further, get Net Business Income After Taxes $(\pi)$ as a sum of four broad components: net civilian production (Dciv $+X c i v)$, military production $(D m i l+X m i)$, net government transfers to business $(I D D+S U B-T d)$ and, finally, business-sector wages and salaries $(-W b)$.

This definition resembles the early work of Kalecki (1933) on the "Determinants of Profits." Unlike Kalecki, however, we do not make a claim for any unidirectional causality here. The net profit on the left-hand side of Table 4 denotes the source of accumulation, while the components on the right-hand side reflect the various modes of accumulation, and, in our opinion, both were "determined" as part of the same historical evolution of authority/property relationships in Israel.

\section{Decomposition}

One way to bring those authority/property relations into the macroeconomic center-stage is by decomposing $\pi$ into its two dual-market components: $\pi_{L}$ which denotes the Net Business Income After Taxes, or net profit, earned by the large firms of the "big economy," and ( $\pi_{S}$ which designates the remaining net profit going to the smaller, periphery firms. As we argued earlier, the profits of these two sectors followed distinctly different patterns, and if this were true for the source of accumulation, then we should not be surprised to find that the two sectors also differed in their respective modes of 
Table 2

Net Business Income After Taxes

\begin{tabular}{|c|c|c|c|c|}
\hline & & Dciv & $\begin{array}{l}\text { Net C } \\
\text { Dome }\end{array}$ & $\begin{array}{l}\text { ivilian Production for } \\
\text { stic Use }\end{array}$ \\
\hline & & & Cld & $\begin{array}{l}\text { Private Consumption } \\
\text { less Dwelling }\end{array}$ \\
\hline & & & Inet & Net Investment \\
\hline & & & Gciv & Government \\
\hline & & & & Consumption \\
\hline & & & & Expenditures, Civilian \\
\hline & & & & Procurement \\
\hline & & & $-M c i v$ & Civilian Imports \\
\hline & & & & $\begin{array}{l}\text { Indirect Business } \\
\text { Taxes }\end{array}$ \\
\hline & & Xciv & $\begin{array}{l}\text { Civilia } \\
\text { for } \mathrm{Ex}\end{array}$ & $\begin{array}{l}\text { in Production } \\
\text { port }\end{array}$ \\
\hline & & Dmil & $\begin{array}{l}\text { Milita } \\
\text { Dome }\end{array}$ & $\begin{array}{l}\text { ry Production for } \\
\text { stic Procurement }\end{array}$ \\
\hline & & & Gmil & Government \\
\hline$\pi \quad$ Net Business & & & & Consumption \\
\hline Income After Taxes & $\equiv$ & & & Expenditures, Military \\
\hline & & & & Procurement \\
\hline & & & - Mmil & Military Imports \\
\hline - & & $X m i l$ & $\begin{array}{l}\text { Milita } \\
\text { Expor }\end{array}$ & ry Production for \\
\hline & & $\mathbb{I D D}$ & $\begin{array}{l}\text { Intere } \\
\text { Dome }\end{array}$ & $\begin{array}{l}\text { st Payments on the } \\
\text { stic Debt }\end{array}$ \\
\hline & & $S U B$ & Subsi & dies to Business \\
\hline & & $-T d$ & Direct & Business Taxes \\
\hline & & $-W b$ & $\begin{array}{l}\text { Busine } \\
\text { and } \mathrm{Sa}\end{array}$ & $\begin{array}{l}\text { ss-Sector Wages } \\
\text { laries }\end{array}$ \\
\hline & & & $-W$ & Wages and Salaries \\
\hline & & & Gumil & Government \\
\hline & & & & Consumption \\
\hline & & & & Expenditures, Military \\
\hline & & & & Wages and Salaries \\
\hline & & & Guciv & Government \\
\hline & & & & Consumption \\
\hline & & & & Expenditures, Civilian \\
\hline & & & & Wages and Salaries \\
\hline
\end{tabular}


accumulation. In operational terms, we could begin by summarizing Table 4 with Equation (2):

$$
\begin{gathered}
\pi \equiv D c i v+X c i v+D m i l+X m i l+ \\
I D D+S U B-T d-W b
\end{gathered}
$$

and then break down into:

$$
\begin{aligned}
\pi_{L} \equiv & \alpha_{1} D c i v+\alpha_{2} X c i v+\alpha_{3} D m i l+\alpha_{4} X m i l+ \\
& \alpha_{5} I D D+\alpha_{6} S U B-\alpha_{7} T d-\alpha_{8} W b \\
\pi_{S} \equiv & \beta_{1} D c i v+\beta_{2} X c i v+\beta_{3} D m i l+\beta_{4} X m i l+ \\
& \beta_{5} I D D+\beta_{6} S U B-\beta_{7} T d-\beta_{8} W b
\end{aligned}
$$

such that, $\pi=\pi_{L}+\pi_{S}$

One straightforward interpretation for the $\alpha_{i}$ and $\beta_{i}$ coefficients of Equations $(3 a)$ and $(3 b)$ is that they represent non-negative distributive shares. For instance, $\alpha_{i}$ would be the share of the "big economy" in Civilian Production for Domestic Use (Dciv), while $\beta_{8}$ would similarly denote the share of the "small economy" in Business-Sector Wages $(W b)$. Since the "big" and "small" economies comprise the entire business sector, the sums $\left(\alpha_{i}+\beta_{l}\right)$ have unit values. None of these coefficients is necessarily fixed through time, of course.

The significance of this decomposition becomes apparent when we relate the disaggregate Equations (3a) and $(3 b)$ to the aggregate Equation (2). In the industrial-organization literature, the term "aggregate concentration" is commonly used to denote the distributive share of the largest firms in key variables such as manufacturing output, industrial sales, or nonfinancial assets. Extending this concept to net business income after taxes $\pi$, we can similarly define the aggregate concentration of profit $(A C)$ as given by the distributive share of profit going to the "big economy," and a complementary index for the aggregate dispersion of profit $(A D)$, to denote the corresponding share going to the remaining smaller firms. These indices are given by Equations (4a) and (4b), respectively: 


$$
\begin{aligned}
A C \equiv \frac{\pi_{L}}{\pi}= & \frac{\alpha_{1} D c i v+\alpha_{2} X c i v+\alpha_{3} D m i l+\alpha_{4} X m u l+}{D c i v+X c i v+D m i l+X m i l+} \\
& \frac{\alpha_{5} I D+\alpha_{6} S U B-\alpha_{7} T d-\alpha_{8} W b}{D D+S U B-T d-W b} \\
A D \equiv \frac{\pi_{S}}{\pi}= & \frac{\beta_{1} D c i v+\beta_{2} X c i v+\beta_{3} D m i l+\beta_{4} X m i l+}{D c i v+X c i v+D m i l+X m i l+} \\
& \frac{\beta_{5} I d d+\beta_{6} S U B-\beta_{7} T d-\beta_{8} W b}{I D D+S U B-T d-W b}
\end{aligned}
$$

where $A C+A D=1$.

Focusing on Equation (4a), we note that the aggregate concentration of profit $(A C)$ could change for two different reasons. First, it could rise or fall as a consequence of changes in the $\alpha_{i}$ coefficients, that is, in the distributive shares of the "big economy" in the $i$ th variable. For instance, a ceteris paribus increase in $\alpha_{1}$ (the "big-economy" share in Civilian Production for Domestic Use, Dciv), or in $\alpha_{5}$ (its share of Interest Payments on the Domestic Debt, IDD), would cause $A C$ to rise, while increases in $\alpha_{7}$ (the "big-economy" share of Direct Business Taxes, Td), or in $\alpha_{8}$ (its share of Business-Sector Wages and Salaries, $W b$ ), would cause $A C$ to fall. (These developments would have precisely the opposite effects on the aggregate dispersion of profit, $A D$.)

The second source for changes in the aggregate concentration of profit are variations in the relative weights of the different variables. To illustrate this impact, assume that $\alpha_{1}$, the share of the "big economy" in Civilian Production for Domestic Use (Dciy), is fixed at 0.7 , while $\alpha_{4}$, its share in Military Production for Export (Xmil), is fixed at 0.9. Now, suppose that, over a given time interval, the only changes in Equation (4) are a reduction in Dciv from $\$ 15$ billion to $\$ 14$ billion, compensated by an increase in $X$ mil from $\$ 1$ billion to $\$ 2$ billion. Following these changes, $\left(\pi_{L}\right.$ would rise by $0.7(14-15)+0.9(2-1)=\$ 0.2$ billion. Since $\pi$ is assumed to have remained unaltered, the aggregate concentration of profit $(A C)$ would increase after these changes by ( $\$ 0.2$ billion)/ $\pi$. We could state that, as long as $\pi$ is fixed, a rise in the value of a variable in which the "big 
economy" has a relatively high distributive share, coupled with a compensatory decline in a variable in which it has a lower distributive share, would have the net effect of raising the aggregate concentration of profit $(A C$ ). In general, the impact of relative-weight changes on $A C$ is more complicated, depending not only on the effect they have on $\pi_{L}$, but also on how they influence $\pi$.

Equations (4a) and (4b) provide us with a quantitative tool for describing a central aspect in the qualitative transformation of Israel's political economy. This is achieved by integrating the country's aggregate economic performance, as indicated by the different components of civilian production, military production, transfers and cost, together with the disaggregate evolution of its underlying institutional arrangements, reflected both in the distributive shares of the "big" and "small" economies in each of the macroeconomic variables, as well as in the aggregate concentration (and dispersion) of net profit.

The "macro" and "micro" histories of the Israeli economy stemmed from the same structural transformation, in which the archaic pre-state institutions of a "mixed economy" gradually gave way to those of a mature, highly concentrated economy, with a growing dual-market demarcation and a persistent "military bias." In this process, the compositional shifts between components of the national accounts were affected by the same forces that altered the overall distribution of profit between the corporate core and periphery. Thus, the temporal increase in the ratio of military to civilian production (Dmil/Dciv), for example, must be seen as part of the same historical process that also raised $\alpha_{3}$ and lowered $\alpha_{1}$. Furthermore, while these developments on the right-hand side of Equation (4a) may have led to a higher aggregate concentration of profit on the left-hand side, they were also very much the consequences of higher concentration. Indeed, one could conceivably argue that, without the differential growth in the net profit of the "big economy," there would have been little or no "military bias" to begin with. Bearing these considerations in mind, we turn now to examine the empirical implications of our framework.

\section{THE MODEL}

Most broadly, the analysis in this section seeks to clarify the following three questions: 
1. Within the broader context of a closed "national-accounting / dual-economy" model, how were the separate business performances of the "big" and "small" economies related to changes in the same macroeconomic components? Specifically, did aggregate variations in military and civilian production (as well as in wage costs and various transfers) carry the same implications for the net profit of the two corporate groups, or were these influences different?

2. If given macroeconomic changes had different consequences for the two dual-economy sectors, how did they affect the differential accumulation process? In particular, which macroeconomic categories tended, as they changed, to augment the aggregate concentration of profit? Which tended to abate it? And which have left it unaltered?

3. Finally, given the pattern of these relationships, how have the actual macroeconomic variations altered the aggregate concentration of profit? Most importantly, how significant was the gradual militarization of the Israeli economy in that process?

To answer these questions, we turn from the identities of the third section into the realm of econometric modelling. Before doing so, however, we need to address two principal difficulties. The first problem is one of instability. As noted earlier, there is no reason for the distributional coefficients $\left\{\alpha_{i}\right.$, $\left.\beta_{1}\right\}$ to have remained stable over time. Indeed, one of the most significant manifestations of Israel's economic restructuring was the changing relationships between the macroeconomic variables on the one hand, and the profits of the "big" and "small" economies on the other. So, seen from a long-term perspective, these relationships were potentially nonstationary. Unfortunately, there are no systematic data on the separate activities of the "big" and "small" economies to help us identify the nature of this non-stationarity. For instance, unlike in the United States, the Israeli government publishes no data on military contract awards. (In fact, there is no official or even unofficial listing of the large military contractors in Israel.) Similarly, there are no size breakdowns for the different component of civilian production, transfers, taxes and costs. The problem is not merely that the disaggregate data are not made public, in order to preserve confidentiality, for example. Based on what we were repeatedly told by top public officials 
and research directors at the Ministry of Finance, the Central Bureau of Statistics and the Bank of Israel, these statistics apparently do not exist at all. This lack of data is, of course, why we need to turn to estimation in the first place, but that also makes it difficult to specify the nature of parameter change. In the absence of such prior knowledge, we solve the problem by means of Chow Tests for structural change.

The second problem concerns the data on profit. As it stands, there is no systematic information on the size distribution of Israeli firms and that makes it difficult to separate $\pi$ into its two dual-economy components, $\pi_{L}$ and $\pi_{S}$. (Despite it small size and high corporate concentration, Israel's national accounts are mapped only from the expenditure side, and there is no systematic breakdown of the income side. For a detailed examination of Israeli data deficiencies, see Bichler (1991). For our purpose here, however, the problem could be readily solved by adopting a slightly different demarcation that separates the business sector into the five core conglomerates on the one hand, and all remaining firms on the other. Given that the net profit of the large core and satellite corporations tend to follow a similar temporal, the former could be used as a reasonable proxy for variations in the net income of the entire "big economy." Moreover, under these conditions, an index of aggregate profit concentration based on the distributive share of the five core conglomerates will tend to move together with a one based on the share of the "big economy" as a whole. With this separation, the net profit of the remaining "other" firms is, of course, somewhat less meaningful because, in addition to the earnings of the "small economy," it also includes the profit of the satellite corporations inside the "big economy." (It should be emphasized that, because the border line between the "big" and "small" economies is always arbitrary to some extent, the difficulty of separating them pervades all concentration indexes, and would persist even if we knew the size distribution of firms. In any case, making the satellite firms part of the "small economy" creates a bias against confirming our hypothesis about differential accumulation.)

These considerations require that we amend and reinterpret the empirical counterparts of Equations (3a), (3b), (4a) and (4b). Suppose for analysis of time-series, we specify two basic empirical equations - one for the core corporations (5a) and another for the "others" (5b) - such that 


$$
\begin{gathered}
\pi_{c}=a_{0}+a_{1} D c i v+a_{2} X c i v+a_{3} D m i l+a_{4} X m i l+ \\
a_{5} I D D+a_{6} S U B-a_{7} T d-a_{8} W b+u
\end{gathered}
$$

and

$$
\begin{aligned}
\pi_{0}= & b_{0}+b_{1} D c i \nu+b_{2} X c i v+b_{3} D m i l+b_{4} X m i l+ \\
& b_{5} I D D+b_{6} S U B-b_{7} T d-b_{8} W b+\nu
\end{aligned}
$$

where $\pi_{c}$ and $\pi_{o}$ are, respectively, the net profit of the five core conglomerates and the "others," $\left\{a_{i}, b_{i}\right\}$ are regression coefficients assumed constant throughout some time period, and $\{u, v\}$ are stochastic errors. Note that, unlike the $\alpha_{i}$ and $\beta_{i}$ parameters, which denote distributive shares, the slope coefficients $a_{i}$ and $b_{i}$ represent the separate impact on $\pi_{c}$ and $\pi_{0}$ of changes in the respective macroeconomic variables. Because these macroeconomic changes may have opposite effects on the profits of the core conglomerates and of the "others," the slope coefficients could be negative or exceed .unity, though the sum $\left(a_{i}+b_{i}\right)$ would still be one. ${ }^{18}$

Given the complementarity of our dual-economy framework, we focus our empirical analysis only on one of these equations. Using equation (5a), our conclusions would then pertain specifically to the core corporations and their relative position within the business sector. Provided that the other large firms shared a similar experience, these conclusions could then be provisionally extended for the entire "big economy." A more systematic study with specific reference to the "small economy" will have to wait until more detailed statistics become available.

${ }^{18}$ To illustrate that possibility, suppose that there was an overall net increase of 1 billion NIS in Military Production for Domestic Use (Dmil), consisting of a rise in military production by the core corporations from 7 to 8.5 billion NIS, coupled with a contemporaneous reduction for the "others" from 3 to 2.5 billion NIS. Everything else remaining the same, the overall effect of this macroeconomic change would be to increase business sector profit ( $\pi$ ) by 1 billion NIS. The disaggregate impact, however, would be to raise the profits of the core $(\pi)$ by 1.5 billion NIS and to lower those of the "others" $\left(\pi_{\partial}\right)$ by 0.5 billion NIS. 


\section{Structural Change}

Our data are annual and cover the period from 1966 to 1985. ${ }^{19}$ The nature of institutional restructuring over this time span was, in many ways, continuous, but there was one historical crossroad that signified a meaningful change in direction, and which might have been associated with a significant "structural change" in the values of regression coefficients. This turning point was marked by the rise to power in 1977 of the right-wing Likud bloc. Regardless of its immediate causes, this political "earthquake" was the climax of the open concentration process that began in the late 1960s: the "mixed economy" was officially over and the newly declared policy of laissez-faire meant that the large conglomerates could henceforth reign supreme. How did this transition affect our empirical equations? Which coefficients were subject to structural change? Which of them remained relatively unchanged?

In order to gain some initial insight into this transformation, we examined individual scatter diagrams, each associating the core's profits $\pi_{c}$ with a separate macroeconomic variable from the right-hand side of Equation (5a). Such diagrams ignore the concurrent effects on $\pi_{c}$ of the other macroeconomic variables, but they are often helpful in indicating major shifts in the particular relationship under examination. Four of these diagrams - those for Dciv, Xciv, Dmil and $T d$ - suggested that, sometime around 1977, there was a substantial change in the relationship between each of these variables and $\pi_{c}$. There was no indication of a similar structural change in the diagrams for $X m i l, I D D, S U B$ and $W b$. Thus, to the extent that there was a structural change in 1977 , we assume it affected only the parameters for Dciv, Xmil, Dmil, Td and the intercept.

Based on these considerations, we formulate the core's augmented profit equation for the 1966-1985 period, as follows:

${ }^{19}$ In 1986, Israel's Central Bureau of Statistics altered its national accounts definitions to be consistent with the 1968 recommendations of the United Nations. Unfortunately, restated data go back only until 1980 and are hence insufficient for our purpose here. Moreover, given the numerous differences between the previous and current definitions, there is no simple way to augment our 1966-1985 data (which are based on the earlier system) by the post-1985 figures that follow the new definitions. 


$$
\begin{aligned}
\pi_{c}= & a_{1} C 7+a_{2} C 8+a_{3} D c i v 7+a_{4} D c i v 8+a_{5} X c i v 7+ \\
& a_{6} \text { Xciv } 8+a_{7} D m i l 7+a_{8} D m i l 8+a_{9} X m i l+a_{10} D D \\
& a_{11} S U B-a_{12} T d 7-a_{13} T d 8-a_{14} W b+u_{4}
\end{aligned}
$$

where a suffix of 7 denotes the relevant variable until 1977 (inclusive) and a string of zeros thereafter, while a suffix of 8 indicates a string of zeros until 1977 (inclusive) and the relevant variable after that. In this equation, $C$ is a unit constant. The error term $u$ represents the average effect on $\pi_{c}$ of errors and omissions involved in estimating the macroeconomic categories on the right-hand side. This error is assumed to fulfill the standard requirements of the classical linear regression model, including normality. In estimating, all data were expressed in 1980 prices. Macroeconomic data are from the Central Bureau of Statistics and the Ministry of Finance. Profit data for the core conglomerates are from their annual reports. Earnings for the "others" are imputed by subtracting from the net income of the business sector the corresponding figure for the core conglomerates. ${ }^{20}$

Based on a series of relevant $F$-tests, we have tentatively concluded that the structural change in 1977 was limited only to the coefficients associated with $X c i v, D m i l$, and $T d$, and that there was no structural change in the coefficient of Dciv. By accepting the outcome of these $F$-tests, the final model for the core firms is given by:

$$
\begin{aligned}
\pi_{c}= & a_{1} C 7+a_{2} C 8+a_{3} D c i v+a_{4} X c i v 7+a_{5} X c i v 8+ \\
& a_{6} D m i l 7+a_{1} D m i l 8+a_{8} X m i l+a_{9} I D D+ \\
& a_{10} S U B-a_{11} T d 7-a_{12} T d 8-a_{13} W b+u
\end{aligned}
$$

To maintain the general complementarity of slope coefficients between the core conglomerates and the "others," the specification of Equation ( 7 a) requires that we adopt a similar

${ }^{20}$ Specific data sources and test results are available upon request from the authors. 
Table 3

Profit Equations for the Core Corporations and the "Others" (OLS Estimates, annual data)

\begin{tabular}{|c|c|c|c|c|}
\hline $\begin{array}{l}\text { Independent } \\
\text { Variable }\end{array}$ & $\begin{array}{l}\text { Core } \\
\text { Corporations } \\
\text { (6) }\end{array}$ & $\begin{array}{l}\text { Core } \\
\text { Corporations } \\
\text { (7a) }\end{array}$ & $\begin{array}{l}\text { "Others" } \\
\text { (7b) }\end{array}$ & $\begin{array}{l}\text { Sum of } \\
\text { Estimates }\end{array}$ \\
\hline$C 7$ & $\begin{array}{l}-214.0 \\
(2.07)\end{array}$ & $\begin{array}{l}-238.2 \\
(2.31)\end{array}$ & $\begin{array}{l}238.2 \\
(2.31)\end{array}$ & 0 \\
\hline$C 8$ & $\begin{array}{l}-2921.1 \\
(3.17)^{\star}\end{array}$ & $\begin{array}{l}-2370.4 \\
(2.97)^{\star}\end{array}$ & $\begin{array}{l}2370.4 \\
(2.97)^{\star}\end{array}$ & --- \\
\hline Dciv7 & $\begin{array}{l}-0.016 \\
(2.20)\end{array}$ & --- & --- & --- \\
\hline Dciv8 & $\begin{array}{l}-0.074 \\
(1.40)\end{array}$ & --- & --- & -.. \\
\hline Dciv & --- & $\begin{array}{l}-0.015 \\
(2.02)\end{array}$ & $\begin{array}{l}1.015 \\
(139.5)^{\star \star \star}\end{array}$ & 1 \\
\hline Xciv7 & $\begin{array}{l}-0.12 \\
(11.39)^{\star \star \star}\end{array}$ & $\begin{array}{l}-0.13 \\
(11.55)^{\star \star \star}\end{array}$ & $\begin{array}{l}1.13 \\
(103.8)^{\star \star \star}\end{array}$ & 1 \\
\hline Xciv8 & $\begin{array}{l}-0.24 \\
(7.96)^{\star \star \star}\end{array}$ & $\begin{array}{l}-0.21 \\
(16.77)^{\star \star \star}\end{array}$ & $\begin{array}{l}1.21 \\
(97.81)^{\star \star \star}\end{array}$ & 1 \\
\hline Dmil7 & $\begin{array}{l}0.016 \\
(0.96)\end{array}$ & $\begin{array}{l}0.018 \\
(1.05)\end{array}$ & $\begin{array}{l}0.982 \\
(57.0)^{\star \star \star}\end{array}$ & 1 \\
\hline Dmils & $\begin{array}{l}1.07 \\
(5.72)^{\star \star}\end{array}$ & $\begin{array}{l}0.89 \\
(8.42)^{\star \star \hbar}\end{array}$ & $\begin{array}{l}0.11 \\
(1.02)\end{array}$ & 1 \\
\hline Xmil & $\begin{array}{l}0.69 \\
(12.66)^{\star \star \star}\end{array}$ & $\begin{array}{l}0.74 \\
(21.70)^{\star \star \star}\end{array}$ & $\begin{array}{l}0.26 \\
(7.55)^{\star \star \star}\end{array}$ & 1 \\
\hline$I D D$ & $\begin{array}{l}0.58 \\
(14.09)^{\star \star \star}\end{array}$ & $\begin{array}{l}0.55 \\
(19.83)^{\star \star \star}\end{array}$ & $\begin{array}{l}0.451 \\
(16.31)^{\star \star \star}\end{array}$ & 1 \\
\hline SUB & $\begin{array}{l}-0.38 \\
(13.08)^{\star \star \star}\end{array}$ & $\begin{array}{l}-0.40 \\
(15.94)^{\star \star \star}\end{array}$ & $\begin{array}{l}1.40 \\
(55.52)^{\star \star \star}\end{array}$ & 1 \\
\hline Td7 & $\begin{array}{l}0.25 \\
(7.38)^{\star \star \star}\end{array}$ & $\begin{array}{l}0.26 \\
(7.51)^{\star \star \star}\end{array}$ & $\begin{array}{l}-1.26 \\
(36.41)^{\star \star \star}\end{array}$ & 1 \\
\hline
\end{tabular}




\begin{tabular}{lllll}
$T d 8$ & -0.60 & -0.63 & -0.37 & 1 \\
& $(15.89)^{\star \star \star}$ & $(20.64)^{\star \star \star}$ & $(12.33)^{\star \star \star}$ & \\
$W b$ & 0.070 & 0.074 & -1.074 & 1 \\
& $(6.36)^{\star \star}$ & $(7.21)^{\star \star \star}$ & $(104.3)^{\star \star \star}$ & \\
$R^{2}$ & 0.999 & 0.999 & 0.999 & \\
AdjR $^{2}$ & 0.998 & 0.998 & 0.999 & \\
$\mathrm{D}-\mathrm{W}$ & 3.03 & 2.90 & 2.90 & \\
\hline
\end{tabular}

Note: $t$-statistics are in brackets

$P<0.05$ (two-tailed test) *

$P<0.01$ (two-tailed test) $\star \star$

$P<0.001$ (two-tailed test) $* \star \star$

formulation as the final model for the rest of the business sector:

$$
\begin{aligned}
\pi_{0}= & b_{1} C 7+b_{2} C 8+b_{3} D c i v+b_{4} X c i v 7+b_{5} X c i v 8+ \\
& b_{6} D \text { mill }+b_{7} D \text { mill }+b_{8} X m i l+b_{9} D D+ \\
& b_{10} S U B-b_{11} T d 7-b_{12} T d 8-b_{13} W b+v
\end{aligned}
$$

where $\{b i\}$ are unknown coefficients and $v$ is an error term. Table 3 provides least-squares estimates for Equations (6), (7a) and $(7 b)$, as well as indicating the arithmetic unit sum for corresponding slope estimates in Equations (7a) and (7b). ${ }^{21}$

The results indicate that 9 of the 11 slope coefficients in the core's final Equation (7a) are significantly different from zero at the 0.001 level, and only two have associated significance levels higher than $0.05 .^{22}$ The parameter estimates of Equation (7a) also appear to be stable. We estimated this same equation

${ }^{21}$ Note that unit sums of estimates are not derived from constrained estimation; they are rather a necessary consequence of the national-accounting identities on which these equations are based.

${ }^{22}$ The value of 2.90 for the Durbin Watson statistics of Equation (7a) indicates the possibility of a first-order autoregressive process for the error term, such that $u_{t}=\rho u_{t-1}+\xi_{t}$, where $\xi_{t}$ is "white noise." We estimated equation ( 7 a) with such an autoregressive correction, but there were no meaningful changes in any of the parameters. 
with 18 different subsamples of our data set - each omitting three different consecutive observations - and found that all the coefficients remained fairly stationary (indeed, only one of the 216 estimated slope-coefficients experienced a sign reversal).

This stability seems to support our initial premise that we could approximate the temporal non-linearity of the model by allowing a single "structural change" in the otherwise stationary parameters. Finally, interpreting the slope coefficients of equations (7a) and (7b) as marginal distributive shares (that is, the shares of the core and the "others" in the change of the macroeconomic variable) means that the value of corresponding pairs of coefficients should sum up to one, by definition.

\section{Macroeconomic Changes and the Process of Differential} Accumulation

The final preparatory step is to set appropriate criteria for testing the effect of macroeconomic changes on the aggregate concentration of profit. Suppose each of the macroeconomic variables is classified as "concentration-augmenting," "concentration-neutral," or "concentration-abating" - depending on whether its associated slope coefficient $a_{i}$ exceeds, equals, or falls short of the contemporaneous aggregate concentration of profit $(\pi d \pi)$, or minus $\pi \pi$ for $T d$ and $W b$. In practice, the designation of a variable in the three classes may change from year to year. Here, however, we are limited to a comparison of the estimated coefficients with the average ratio for aggregate concentration during the period in which the parameter has presumably remained stationary. Defining the "average aggregate concentration" $\left(A A C_{T}\right)$ as the average $\pi_{c} / \pi$ ratio prevailing in time interval $T$, we adopt an amended terminology based on the relationships between the value of coefficients and the corresponding $A A C_{\mathrm{T}} \mathrm{s}$. Thus, among those variables which have a positive impact on the aggregate profit $\pi$ (namely, Dciv, Xciv, Dmil, Xmil, $I D D$ and $S U B)$, we could distinguish between "concentration-augmenting," "concentration-neutral" and "concentration-abating" variables depending on whether $a_{i}$ was greater than, equal to or smaller than $A A C_{\mathrm{T}}$, respectively. On the other hand, variables which have a negative impact on $\pi$ (that is, $T d$ and $W b$ ) should be classified as being "concentration-augmenting," "concentration-neutral" or "concentration-abating" if $a_{i}$ was smaller than, equal to or greater than $A A C_{\mathrm{T}}$. 
The values of $A A C_{\mathrm{T}}$ in our sample were 0.026 for the 1966-1977 period, 0.143 for the $1978-1985$ period, and 0.073 for the entire 1966-1985 period. Using these as relevant benchmarks, we tested the hypotheses that individual parameters were equal to the average aggregate concentration of profit over the relevant period. If, based on the $F$-test, any null hypothesis could not be rejected, we concluded that the variable had no definite effect on the concentration process, and was, therefore, concentration-neutral. If the null hypothesis was rejected, however, we concluded that the variable was concentration-augmenting or concentrationabating, depending on whether the estimated coefficient was greater or smaller than $A A C_{\mathrm{T}}$ as described above.

The Historical Restructuring of the Israeli Economy: An Empirical Assessment

Restated briefly, our goal is to assess the structural role of broad macroeconomic developments, particularly those related to the "military bias" of Israeli industry. Operationally, we seek to examine (1) the extent to which macroeconomic changes had different effects on the profits of the "big" and "small" economies, (2) the direction in which such macroeconomic changes tended to influence the process of differential accumulation and resulting aggregate concentration of profit and (3) the combined impact of parameter differentials and macroeconomic compositional shifts on the historical progression of aggregate concentration. We begin with the first two questions, which depend on the values of estimated parameters and could be addressed together, and then turn to the third question, which relates to the values of both estimated coefficients and regression variables. (In assessing our findings, we focus primarily on the core's equation. The results for the "others" satisfy the unity requirement for the slope coefficients $\left(a_{i}+b_{j} \cdot\right)$

1. Civilian Production. Based on the F-tests, both Civilian Production for Domestic Use (Dciv) and Civilian Production for Export (Xciv) appear to be concentration-abating variables. Indeed, the coefficient estimates for the two variables are negative, which means that increases in each of these macroeconomic categories tended to reduce the profits of the core conglomerates. According to equation ( $7 \mathrm{a})$, the structural change occurring in 1977 lowered the Xciv coefficient from -0.13 to -0.21 , thus further intensifying the concentration- 
abating effect of this variable. (The corresponding coefficient estimates for the "others" are all positive.)

This evidence suggests that increases in the macroeconomic magnitude of civilian production were brought about by a combination of even larger increases for the "small economy," coupled with declines in the "big economy." In fact, this kind of structural divergency seems to characterize the dynamics of most macroeconomic categories in our modell (Of the 11 slope parameters, only the coefficients of Dmil7, Dmils, Xmil, IDD and Td8 exhibit the same sign for the core and for the "others.") This pattern may be typical to a stagnant economy with strong distributional coalitions, and it reinforces our emphasis on the need for disaggregate analysis.

2. Military Production. In contrast to civilian production, changes in military production tended to be concentrationaugmenting, particularly since the late 1970 s. The estimated coefficient for $D$ mil 7 is 0.018 , and since an $F$-test indicates that this was not significantly different from $A A C_{66-77}$, we conclude that, between 1966 and 1977, Military Production for Domestic Use was concentration-neutral. (The estimated marginal effect of Dmil7 on the "others" profit was 0.98.) In the subsequent 1978-1985 interval, however, there was a dramatic increase in the effect of this variable on the core's profit. The estimated marginal coefficient for Dmils is 0.89 , significantly different from $A A C_{78-85}$ according to our $F$-test, so we conclude that Military Production for Domestic Use in that period became concentration-augmenting. (The corresponding estimate for the "others" dropped to 0.11.) Based on Equation (7a), Military Production for Export (Xmil) was concentration-augmenting during the entire sample period. The estimate for this variable is 0.74 , tested to be significantly different from $A A C_{66-85}$. (The corresponding estimate for the "others" coefficient is 0.26 .) These findings suggest that, during the first period between 1966 and 1977, the neutral effect of Dmil on concentration was counteracted by the positive effect of $X$ mil, and, as we demonstrate later in this section, the combined effect of the two military-production categories was concentrationaugmenting. This combined positive effect intensified after the structural change of 1977, when Dmil, too, became concentration-augmenting.

So far, these conclusions regarding civilian and military production are consistent with our basic hypothesis about the positive link between the "military bias" of the Israeli economy and its aggregate concentration. The "military bias" since the 
early 1970s occurred through a relative decline in civilian activity as opposed to military-related production (Figure 1), and if our findings are generally correct, this relative shift must have contributed to the process of differential accumulation and consequent increase in the aggregate concentration of net profit. Before we assess this effect more closely, however, it is necessary to examine the marginal effect on concentration of the other macroeconomic variables in our model.

3. Government-Business Transfers. In general, changes in $I D D, S U B$ and $T d$ seem to have had different and often opposite effects on the net profit of the core conglomerates and of the "others." The estimated marginal effect of $I D D$ on the core's profits is 0.55 , and based on an F-test, we conclude that Interest Payments on the Domestic Debt were concentration-augmenting. (The comparable estimate for the "others" is 0.45.) In light of the fact that the domestic debt in Israel was financed almost exclusively by the large institutional investors of the "big economy," this inference about the concentration-augmenting effect of IDD should hardly be surprising.

The estimated marginal impact of Business Subsidies (SUB) - on net profit is negative for the core conglomerates $(-0.40)$ and positive for the "others" $(1.40)$, and this variable was $F$-tested to be concentration-abating. To see why this should be so, note that, because they include the "small economy," the "others" typically have lower profit margins on sales than the core conglomerates, which in turn implies that the rate of aggregate concentration for sales is lower than the corresponding aggregate concentration for profit. If subsidies are proportionate to sales (rather than to profit), and if that proportion is roughly similar for the two sectors, it follows that increases in such subsidies are bound to reduce the aggregate concentration of profit. ${ }^{23}$ It must be noted, however, that, in addition to direct subsidies associated with specific products, the Israeli government also provides subsidized loans to particular companies. The subsidy component of these loans

${ }^{23}$ For example, suppose that the rate of aggregate concentration for sales is 0.2 , the rate of aggregate concentration for profit is 0.4 , and subsidies are proportionate to sales. Under these conditions, an increase of 1 NIS in SUB will raise the net profit of the "others" by 0.8 NIS and that of the core by 0.2 , thus lowering the rate of aggregate concentration for profit below its initial level of 0.4 . 
is not included in our $S U B$ variable, but we could be fairly certain that its effect on profits is concentration-augmenting, simply because most of the subsidized loans go to the "big economy."24

The effect of Direct Business Taxes changed significantly between the two periods. Until 1977, Td was $F$-tested to be concentration-augmenting. Moreover, with an estimated coefficient of 0.26 in Equation (7a), increases in this variable probably had a positive effect on the profits of the core conglomerates. (The comparable estimated effect for the "others" was -1.26.) This evidence is again consistent with our emphasis on the process of redistribution underlying macroeconomic changes. Within a rigid institutional structure, a small increase (decrease) in overall business taxes could be the sum of a large increase (decrease) in the taxes of the "others," coupled with a decline (rise) in the taxes paid by the large core conglomerates. From 1978 onward, however, the "core" coefficient dropped to -0.63 as Direct Business Taxes became concentration-abating, based on an $F$-test. One possible explanation is that, during that period, the "small-economy" tax base was shrinking, thus shifting the marginal tax burden onto the "big economy." Unfortunately, the size distribution of business taxes is not available, so these speculations could not be verified.

4. Labor Cost. Another dual-economy divergence appears in the coefficient estimates associated with Business-Sector Wages and Salaries $(W b)$. The estimated value for the core is 0.074 (-1.074 for the "others"). All in all, changes in $\mathrm{Wb}$ were $F$-tested to be concentration-augmenting. The interpretation of these findings is, again, that aggregate changes tend to conceal conflicting movements in the underlying shares of the core and the "others." In the Israeli context, these divergent movements may have been related to the dichotomy between the

${ }^{24}$ Data on the subsidy component of government loans are available only since 1975 and hence could not be used in our model. Furthermore, these data are imputed. They are based on the difference between the government and market rates of interests, assuming that the latter represents an equilibrium between the competitive supply and competitive demand for funds. Unfortunately, with Israeli capital markets being completely dominated by the government and the large conglomerates, the "market" rate of interest may have little to do with competitive equilibrium, so this kind of imputation has no clear theoretical meaning. 
Palestinian labor force of the "small economy" and the Jewish labor force of the "big economy," as proposed by Farjoun (1978, $1980,1983)$. One fundamental difference between these two groups has been the pattern of their wage changes. While the average real wage of Jewish employees increased more or less steadily between the late 1960 s and the early 1980 s, that of the Palestinian workers tended to fluctuate Professor-cyclically with the economy's rate of growth. Now, to the extent that these latter fluctuations were the primary source of short-term variations in the overall wage bill, the result for our equations would have been to make the negative impact of $W b$ on the "small-economy" profit disproportionately large. In other words, everything else remaining the same, increases in the total wage bill of the business sector would tend to reduce the net profit of the "others" by more than they reduce those of the core conglomerates. Also, if implicit in the overall increase (decline) of wages, there was a decline (increase) in the wage bill of the core, the associated slope coefficient for this sector could even become positive, as we found in our estimates.

Our conclusions so far were concerned only with patterns of relationship, as indicated by the size and temporal variations of the slope parameters. In order to complete our analysis, however, it is also necessary to examine the effect on aggregate concentration of the actual evolution of the macroeconomic variables. Using a broad classification in which we group together the macroeconomic variables belonging to civilian production (Dciv, Xciv 7 and Xciv8), military production (Dmil7, Dmil 8 and Xmil), government-business transfers (IDD, SUB, Td7 and $T d 8)$ and labor cost $(W b)$, and adding a fifth classification of "intercepts" ( $C 7$ and $C 8$ ), we define the following combined variables:

$$
\begin{aligned}
& \operatorname{CivP}=\left(A_{3} \text { Dciv }+A_{4} \text { Xciv } 7+A_{5} \text { Xciv8 }\right) / \pi \\
& \operatorname{MilP}-\left(A_{6} \text { Dmil } 7+A_{7} \text { Dmil }+A_{8} \text { Xmil }\right) / \pi \\
& \operatorname{TrfP}-\left(A_{4,} I D D+A_{10} S U B-A_{11} T d 7-A_{12} T d 8\right) / \pi \\
& W b P=-A_{13} W b / \pi \\
& \operatorname{IctP}:\left(A_{1} C 7+A_{2} C 8\right) / \pi,
\end{aligned}
$$


Figure 3

Estimated Contributions to the Aggregate Concentration of Net Profits

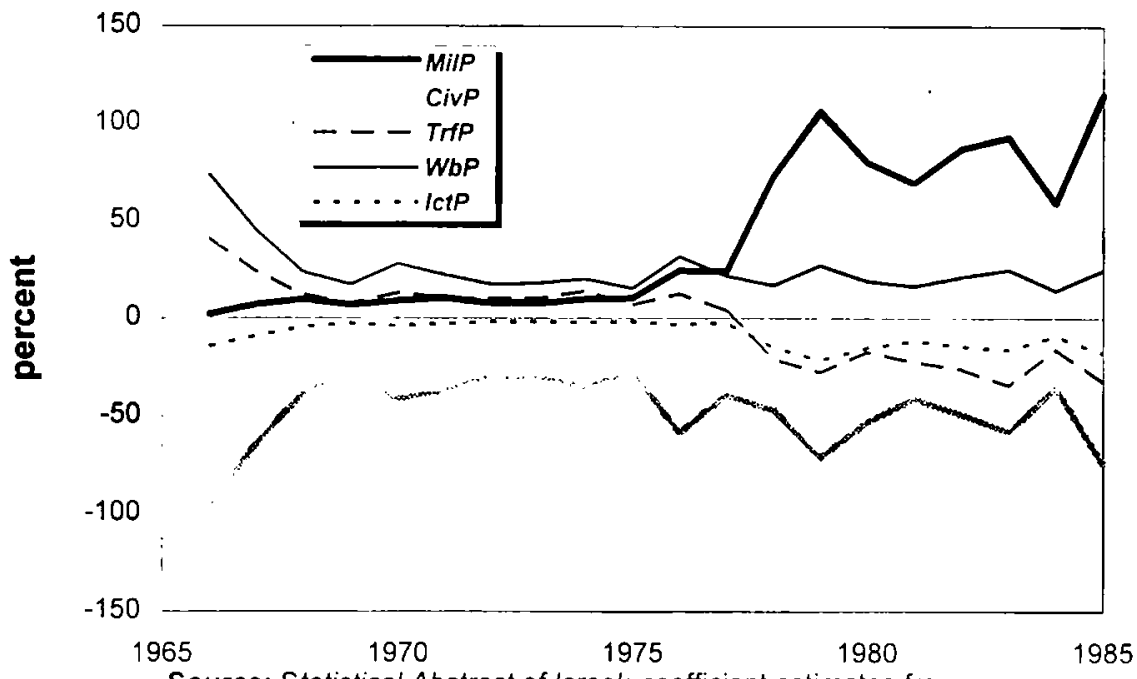

Source: Statistical Abstract of /srael; coefficient estimates from equation (7a).

where $A_{i}$ is the estimated value of $a_{i}$ in equation (7a), as reported in Table 3 . The sum of these five variables is simply the "predicted" aggregate concentration of profit $\left(\pi_{d} \pi\right)$, based on these estimated parameters and the actual values for the carriers of equation (7a). From this perspective, the combined variables listed above could be viewed as representing approximate relative "contributions" to the annual rate of aggregate profit concentration. Specifically, CivP denotes the combined estimated contribution of civilian production, MilP designates the combined estimated contribution of military-related activity, TrfP signifies the combined estimated contribution of government-business transfers, $W b P$ represents the estimated contribution of wage cost, and IctP is simply the ratio of the sum of intercepts and $\pi$. The annual values for these combined variables (expressed as percent of $\pi$ ) are plotted in Figure 3.

In evaluating the historical picture emerging from these data, our concern is of course only with variations, not absolute magnitudes. The most significant impact on the process of differential accumulation, particularly since the mid-1970s, originated from changes occurring in the areas of civilian and 
military production. During the first period of relative prosperity between 1966 and 1977, the most dynamic category was that of civilian production. In the subsequent 1978-1985 period, with the economy reverting into aggregate stagnation, there were marked increases in the variations of the different "contributions," with some variables tending to raise the aggregate concentration of profit and others tending to lower it. While the standard deviation for $W b P$ fell somewhat, that of TrfP almost doubled. The most substantial increases in variability, however, occurred in civilian production and even more so in military-related activity.

Our main conclusion then, is that there was indeed an intimate link between the "military bias" of the Israeli economy and the increasing concentration of profit. While changes in interest payments on the domestic debt, subsidies, business taxes and labor cost have all affected the differential nature of accumulation, the primary root of that process was the fundamental structural transformation from civilian to military-related profitability. This "military bias" evolved in two related ways. First, since the end of the "Palestinian boom," military spending became the principal means of redistributing profit from the "small" to the "big economy." The negative impact on the core's profit of changes in civilian spending and the positive impact of increases in military spending help to explain the gradual diversion of the large conglomerates from civilian to military-related activity. This restructuring intensified after 1977, when the disparities in profitability grew even further. These developments were also associated with a second, parallel transformation. The increasing reliance of the big conglomerates on profits coming from military as opposed to civilian production has contributed to the changing balance between these two sectors. While both military and civilian production were rising in real terms, their ratio was slowly increasing, as illustrated in Figure 1. In other words, the "military bias" consisted of a dual process, involving on the one hand a divergence between rising military profitability and falling civilian profitability, and on the other hand a relative increase in the size of the military as opposed to civilian sector of the Israeli economy.

\section{SUMMARY AND CONCLUSIONS}

Our basic point of departure in this paper was that, in a mature capitalist economy, the evolution of military spending 
must be understood in conjunction with business restructuring, particularly the process of differential accumulation. Examining the "model" case of Israel, we adopted a dual-economy perspective that distinguished the large conglomerates of the "big economy" from the rest of the business sector, and argued that the increase since the late 1960 s in the share of net profit earned by the core conglomerates was positively related to a progressive "military bias" of Israeli industry. In evaluating this link, our goal was not to identify the "determinants" of aggregate profit concentration, or the inevitable "laws of motion" that govern military spending. Instead, we chose a non-deterministic perspective, arguing that the evolution of military expenditures and the process of differential accumulation were two sides of the same historical transformation affecting Israeli society. To study the nature of this transformation, we developed a self-contained analytical framework integrating the distribution of net profit on the micro level, with compositional shifts in the national accounts on the macro level.

Econometric estimates and tests based on this framework tended to confirm our central hypothesis. In general, the regression results showed that the long-term increase in the ratio of military to civilian production was indeed closely correlated with the growing concentration of net profit. Military-related production was expanding most rapidly during the late 1960 s and early 1970 s but, given that civilian economic activity was still much larger, the effect of this "military bias" on the aggregate concentration of profit was relatively limited. Since the mid-1970s, however, with the Israeli economy entering its "monopolistic" phase, civilian production reverted to chronic stagnation, steering the large distributional coalitions of the "big economy" deeper into the military sector. These conclusions are, of course, more suggestive than definitive, and further research is both needed and welcome, but the potential of this line of analysis - for Israel, as well as for other industrial countries - is clearly promising.

Incidentally, our findings in this paper may shed new light on the debated link between military spending and economic growth. Participants who focused primarily on developing countries, such as Benoit $(1973,1978)$, claimed that military expenditures have had a positive influence on economic growth, whereas those who concentrated more on the experience of developed economies, like Smith (1977, 1978, 
1980), contended that these expenditures were in fact detrimental to prosperity. One reason why the views of Benoit and Smith could not be easily reconciled was that both argued in aggregate terms and failed to consider underlying structural differences. Indeed, when we add this extra dimension in the case of Israel, the apparently contradictory perspectives of Benoit and Smith become in fact complementary to one another. During the 1950s and much of the 1960 s, Israel appears to fit the context described by Benoit, with rapid economic growth propagated by militarization. This occurred both directly, through the multiplier effect of military spending, as well as indirectly via the accompanying "socialization" of new immigrants, technological spillovers and the growth of managerial know-how. The period since the late 1960s, however, begins to show the symptoms described by Smith. During the 1970 s and 1980 s, military budgets no longer propped the economy, and instead brought larger debts and growing stagnation. Now, if we follow the central thesis of this paper, then this reversal must be attributed, at least in part, to the changing structure of the Israeli economy. Until the late 1960 s, the Israeli business sector was still relatively dispersed, and in that context, military expenditures (together with expanding populations) were conducive to growth. Gradually, however, the process of corporate concentration created an increasingly rigid structure of "distributional coalitions," which, from the early 1970 s onward, turned military spending into a stagnationary economic force.

This regime of "militarized stagnation" lasted more than a decade, roughly until the late 1980 s, and the apparent reluctance to change it must have been affected by the heightened dependency of the "big economy" on military-related profits. In a certain sense, the whole process became self-propagating: the ongoing rise in the ratio of military to civilian production contributed toward an ever-growing concentration of profit; this augmented the political-economic power of the large conglomerates, which were then in a better position to promote larger defense budgets. Of course, this circularity does not mean that the process could have continued indefinitely and, indeed, by the late 1980s, after more than two decades of an intense "military bias," Israel appeared to have entered a new political phase. The escalating Intifada brought a greater recognition of the Palestinian problem and, with the end of the Cold War, this eventually culminated in a substantial shift toward a 
conciliatory foreign policy. Interestingly, however, the causes for this transition and the prospects for its future success remain dependent on the same structural considerations that also underlay the earlier process of militarization. ${ }^{25}$

As long as the "military-bias" benefits for the large conglomerates outweighed their share in the macroeconomic cost of stagnation, they had little or no interest in reverting to a peace economy. Yet, in order for the military-dependent profits of these firms to continue and rise faster than the economy's average, the militarization of Israeli industry had to intensify, and that, of course, could not go on forever. Indeed, since the late $1980 \mathrm{~s}$, some of the large firms began to have second thoughts about the merits of a war economy. With the government's growing fiscal crisis, the ratio of military to civilian production began to level off indicating that the militarization process may have reached its upper limit. Also, by that time, the core conglomerates were becoming too large for their domestic market and, in seeking expansion, started to see the potential advantages of Middle East integration. In this light, it is then not surprising that, after the beginning of the Intifada in 1987, the large corporations in Israel started to publicly promote the benefits of regional reconciliation. Such support must have weighed heavily in the recent Israeli change of heart about an Israeli-Palestinian settlement, and will remain crucial if the Israeli-Arab peace process is to succeed. From this perspective, one may be even tempted to recommend that the large firms be made the principal "peace-profiteers," so as to assure their continued interest in demilitarization. Indeed, if we could reverse the structural role of military and civilian production, making the former concentration-abating and the latter concentration-augmenting, we may be able to turn the Israeli "big economy" into the best ally of peace. Failing to move in this direction would then leave a constant temptation to revert back to rising military budgets.

\section{REFERENCES}

Aharoni, Y. 1976. Structure and Performance in Israeli Economy. In Hebrew. The Institute for Business Research. Tel Aviv University. Tel Aviv: Gomme Science and Research Books and Tshrikover Publishers.

${ }^{25}$ Detailed analyses of the transition from war profits to peace dividends are given in Bichler (1995), Nitzan and Bichler (1996a, 1996b). 
Baran, P.A. and P.M. Sweezy, 1966. Monopoly Capital. An Essay on The American Economic and Social Order. New York and London: Modern Reader.

Barkai, H. 1968. The Public, Histadrut, and Private Sectors in the Israeli Economy. December. Jerusalem: The Maurice Falk Institute of Economic Research.

1981. The Cost of Defense in Retrospect. In Hebrew.

Discussion Paper 115. The Maurice Falk Institute of Economic Research. Jerusalem.

Barnet, R.J. 1972. The Roots of War. Baltimore: Penguin Books.

Bar Yosef, T. 1987. Restricting the Domestic Market as a Means of Raising Exports. In Hebrew. The Economic Quarterly 37(132): 34-37.

Bejsky. M., V. Ziller, Z. Hirsh, Z. Sarnat and D. Friedman. 1986. Report of the Commission of Inquiry into the Regulation of Banking Shares: Final Report. In Hebrew. Jerusalem: The Government Printer.

Benoit, E. 1973. Defense and Economic Grouth in Developing Countries. Lexington, Mass.: Lexington Books.

. 1978. Growth and Defense in Developing Countries. Economic Development and Cultural Change 26(2): 271-80.

Ben-Porath, Y. (ed.). 1986. The Israeli Economy. Maturing Through Crises. Cambridge, MA.: Harvard University Press.

Berglas, E. 1983. Defense and Economy. Israeli Experience. Discussion Paper 83.01. The Maurice Falk Institute of Economic Research. Jerusalem.

Bichler, S. 1986. The Political Economy of National Security in Israel. Unpublished Master Dissertation. Department of Political Science. Hebrew University. Jerusalem.

1991. The Political Economy of Military Spending In Israel. Unpublished Doctoral Dissertation. Department of Political Science. Hebrew University. Jerusalem.

1995. Political Power Shifts in Israel, 1977 and 1992:

Unsuccessful Electoral Economics or Long Range Realignment? Science and Society 58(4): 415-439.

Bichler, S., R. Rowley and J. Nitzan. 1989. The Armadollar-Petrodollar Coalition: Demise or New Order? Working Paper 11/89. Department of Economics. McGill University. Montreal.

Bowring, J. 1986. Competition in a Dual Economy. Princeton: Princeton University Press.

Bruno, M. 1989. Israel's Crisis and Economic Reform in Historical Perspective. In Hebrew. The Economic Quarterly 40(141): 89-113.

Buawoy, M. and T. Skocpol (ed.). 1982. Marxist Inquiries: Studies of Labor, Class and State. American Joumal of Sociology 88. Supplement.

Elizur, Y. 1984. The Bankers. History of an Adventure. In Hebrew. Jerusalem: Domino Press.

Farjoun, E. 1978. The Palestinian Workers - An Economic Reserve Army. In Hebrew. Red Papers 5. Jerusalem. 
. 1980. Palestinian Workers in Israel - A Reserve Army of Labor. Khamsin 7: 107-143. London.

\section{London.}

Frenkel, S. 1982. The War Profiteers. In Hebrew. 9 Articles. Haolam Hazeh August-November.

Frenkel, S. and S. Bichler. 1984. The Rich Families: Israel's Aristocracy of Finance. In Hebrew. Tel Aviv: Kadim.

Gilshon, A. 1986. Defense and Economic Growth in Israel. In Hebrew. Studies in Economics. pp. 13-33.

Gold, D.A. 1977. The Rise and Decline of the Keynesian Coalition. Kapitailstate 6. Fall. pp. 129-161.

Greenberg, Y. 1986. The Decline and Disappearance Through Mergers of Credit Cooperatives. In Hebrew. The Economic Quarterly 37(137): 757-71.

Griffin, L.J., J.A. Devine and M. Wallace. 1982. Monopoly Capital, Organized Labor and Military Expenditures in the United States, 1949-1976. In, Buawoy and Skocpol (ed.). Marxist Inquiries pp. S1 13-S153.

Gross, N. (ed.). 1975. Economist Panel. Articles on the Economic Policy in Israel. In Hebrew. Tel Aviv: University Publishing Enterprises.

Halperin, A. 1987. Does Military Technology Affect Economic Growth? Working Paper submitted to the International Conference on Technology and Strategy: Future Trends. Tel-Aviv: Tel Aviv University. The Jaffe Center for Strategic Studies.

Hartley, K. and T. Sandler (eds.). 1990. The Economics of Defense Spending. An International Survey. New York and London: Routledge and Kegan Paul.

Hassid, N. and A. Lesser. 1981. Economic Resources for Israel's Security. In Hebrew. Economic Quarterly. 109: 243-52.

Heth, M. 1966. The Banking Institutions in Israel. Jerusalem: The Maurice Falk Institution for Economic Research.

Hilferding, R. 1910, 1981. Finance Capital; A Study of the Latest Phase of Capitalist Development. London: Routledge and Kegan Paul.

Israel. Bank of Israel. Annual Report. various years.

Israel. Central Bureau of Statistics. Statistical Abstract of Israel. various years.

1986. National Accounts, 1972-1985. National Accounts Statistical Series. No. 68.

Kalecki, M. 1933. Determinants of Profits. In, Selected Essays on the Dymamics of the Capitalist Economy. Kalecki (ed.). (1971: 78-92).

. 1964. The Fascism of Our Times. In, The Last Phase in the Transformation of Capitalism Kalecki (ed.). (1972: 99-106).

1967. Vietnam and U.S Big Business. In, Kalecki (1972:107-114).

- 1971. Selected Essays on the Dynamics of the Capitalist

Economy, 1933-1970. Cambridge: Cambridge University Press. 
1972. The Last Phase in the Transformation of Capitalism. New York: Monthly Review Press.

Katzir, Y. and Z. Shadmi 1984. Cutting the Defense Budget - A Key to Economic Recovery? In Hebrew. In, The Cost of Might. Offer and Kover (eds.). pp. 117-123.

Lanir, Z. (ed.). 1985. Israeli Security Planning in the 1980s. Its Politics and Economics. In Hebrew. Tel Aviv University. The Jaffe Center for Strategic Studies. Tel Aviv. Ministry of Defense.

Levi, H. 1979. Capital Structure, Inflation and the Price of Capital in Israeli Industry, 1964-1978. In Hebrew. Discussion Paper 795. The Maurice Falk Institute of Economic Research. Jerusalem.

1981. Capital Structure, Inflation and the Price of Capital in Israeli Industry From 1964 to 1978. In Hebrew. Research Paper 122. The Maurice Falk Institute of Economic Research. Jerusalem.

Luxemburg, R. 1913, 1951. The Accumulation of Capital. New York: Monthly Review Press.

McGuire, M. 1982. U.S. Assistance, Israeli Allocation and the Arms Race in the Middle East. Joumal of Conflict Resolution 26: 199-235.

Melman, S. 1985. The Permanent War Economy. American Capitalism in Decline. New York: Simon and Schuster.

Mills, C.W. 1956. The Power Elite. New York: Oxford University Press.

Mintz, A. and M.D. Ward. 1989. The Political Economy of Military Spending in Israel. American Political Science Review 83(2): 521-533.

Mintz, A. M.D. Ward and S. Bichler. 1990. Defense Spending in Israel. In, Hartley and Sandler (eds.). pp. 177-188.

Nitzan, J. 1992. Inflation as Restructuring. A Theoretical and Empirical Examination of the U.S. Experience. Unpublished Doctoral Dissertation. Department of Economics. McGill University. Montreal.

Nitzan, J. and S. Bichler. 1995. Bringing Capital Accumulation Back In: The Weapondollar-Petrodollar Coalition - Military Contractors, Oil Companies and Middle-East "Energy Conflicts." Review of International Political Economy 2(3): 446-515.

1996a. From War Profits to Peace Dividends - The New Political Economy of Israel. Capital \& Class. Forthcoming.

- 1996b. From War Profits to Peace Dividends - The New

Israeli Political Economy. In Hebrew. In, Ram and Svirsky (eds.). Annual for Critical Studies 1. Tel Aviv: Breirot forthcoming.

Nitzan, J., R. Rowley and S. Bichler. 1989. Changing Fortunes: Armaments and the U.S. Economy. Working Paper 8/89. Department of Economics. McGill University. Montreal.

O'Connor, J. 1973. The Fiscal Crisis of The State. New York: St. Martin's Press.

Offer, Z. and A. Kover (eds.). 1984. The Cost of Might. In Hebrew. Ministry of Defense. Tel Aviv: Ma'arachot.

Olson, M. 1982. The Rise and Decline of Nations. Economic Growth, Stagflation and Social Rigidities. New Haven and London: Yale University Press. 
Patinkin, D. 1965. The Israeli Economy in The First Decade. In Hebrew. Jerusalem: Maurice Falk Institution for Economic Research.

Peri, Y. and A. Neubach. 1985. The Military-Industrial Complex in Israel. A Pilot Study. January. Tel Aviv: International Center for Peace in the Middle East.

Rowley, R., S. Bichler and J. Nitzan. 1988. Some Aspects of Aggregate Concentration in the Israeli Economy, 1964-1986. Working Paper 7/88. Department of Economics. McGill University. Montreal.

. 1989. The Armadollar-Petrodollar Coalition and the Middle

East. Working Paper 10/89. Department of Economics. McGill University. Montreal.

Sadan, E. 1985. National Security and National Economy. In Hebrew. In, Israeli Security Planning in the 1980s. Lanir (ed.). pp. 119-129.

Schumpeter, J.A. 1919, 1951. Imperialism and Social Classes. Translation by H. Norden. New York: Augustus M. Kelley.

Shapiro, Y. 1977. The Democracy in Israel. In Hebrew. Ramat-Gan, Israel: Massada.

1984. An Elite Without Successors. Generations of Political Leaders in Israel. In Hebrew. Tel Aviv: Sifriat Poalim.

Sharkansky, I. 1987. The Political Eoonomy of Israel. New Brunswick, N.J.: Transaction Books.

Smith, R.P. 1977. Military Expenditure and Capitalism. Cambridge Journal of Economics 1(1): 61-67.

- 1978. Military Expenditure and Capitalism: A Reply. Cambridge Joumal of Economics 2(3): 299-304.

. 1980. The Demand for Military Expenditures. Economic Joumal 90. December. pp. 811-20.

Steindl, J. 1952, 1976. Maturity and Stagnation in American Capitalism. New York: Monthly Review Press.

Stockholm International Peace Research Institute. 1992. SLPRI Yearbook, 1992. World Armaments and Disarmament. Oxford: Oxford University Press.

Tsuru, S. 1961. In, Has Capitalism Changed? An International Symposium on the Nature of Contemporary Capitalism. Tsuru (ed.). pp. 1-66.

Tsuru, S. (ed.). 1961. Has Capitalism Changed? An International Symposium on the Nature of Contemporary Capitalism. Tokyo: Iwanami Shoten.

Tuchman, B.W. 1984. The March of Folly. From Troy to Vietnam. New York: Alfred A. Knopf.

Tuma, E.H. 1989. The Economies of Israel and The Occupied Territories: War and Peace. A Panel Discussion. In Hebrew. Economic Quarterly. 139: 593-598.

U.S. Arms Control and Disarmament Agency. 1995. World Military Expenditures and Arms Transfers, 1993-1994. Washington D.C.: GPO.

U.S. Department of Defense. 1992. 100 Companies Receiving the Largest Dollar Volume of Prime Contract Awards, Fiscal Year 1992. Washington, D.C.: GPO. 
Veblen, T. 1904, 1975. The Theory of Business Enterprise. Clifton, NJ: Augustus M. Kelley Publishers. Reprints of Economic Classics. . 1923, 1967. Absentee Oumership and Business Enterprise in Recent Times. The Case of America. With an introduction of $R$. Leckachman. Boston: Beacon Press.

Zusmman, P. 1984. Why is the Security Burden So Heavy in Israel? In Hebrew. In, The Cost of Might. Offer and Kover (eds.). pp. 17-25.? 